\title{
Comparison of the efficacy of static versus articular spacers in two-stage revision surgery for the treatment of infection following total knee arthroplasty: a meta- analysis
}

\author{
Hai Ding*, Jian Yao, Wenju Chang and Fendou Liu
}

\begin{abstract}
Background: The aim of this study was to compare the outcomes of static versus articular spacers in two-stage reimplantation for the treatment of infected total knee arthroplasty (TKA).

Methods: The literature regarding the articulating and static spacers for treating infected TKA were searched in PubMed, Embase, Cochrane Library, Chinese Periodical Full-Text Database of CNKI, and Wanfang database. Data were extracted according to the inclusion and exclusion criteria and analyzed by Review Manager 5.3.

Results: Ten studies were included to this meta-analysis (nine retrospective studies, one prospective study) according to the principle of PICOS. There was no significant difference regarding the eradication rate $(P=0.28)$ and the American Knee Society knee score (KSS) pain score $(P=0.11)$ between the articulating and static spacers in the two-stage revision surgery. There was no significant difference regarding quadriceps femoroplasty and tibial tubercle osteotomy between the two groups $(P=0.50)$. The knee range of motion $(\mathrm{ROM})$, Hospital for Special Surgery (HSS) score, and KSS function score in the articulating group were significantly higher than those in the static group $(P<0.00001)$.

Conclusion: Articulating spacers can provide better ROM and knee function scores after revision surgery when compared to static spacer while not compromising the infection eradication rate, soft tissue contracture during exclusion period, and knee pain scores.
\end{abstract}

Keywords: Total knee arthroplasty, Periprosthetic infection, Two-stage revision arthroplasty, Antibiotic bone cement spacer, Meta-analysis

\section{Background}

The prosthetic joint infection (PJI) is a devastating and complex complication after total knee arthroplasty (TKA). Although the incidence was only 1 to $2 \%$ [1-3], the number of the joint arthroplasties being performed is increasing. It can lead to serious consequences such as bone defect and necrosis; thus, the diagnosis and effective treatment of postoperative infection are very important. The two-stage revision surgery is the "gold standard" for patients with infection following TKA, especially for patients

\footnotetext{
*Correspondence: dinghai_66@163.com

Department of Orthopedics, The First Affiliated Hospital of Bengbu Medical College, No. 287 Changhuai Road, Bengbu, Anhui 233004, People's Republic of China
}

with chronic infection. The implantation of antibioticcontaining bone cement spacers can be used to eradicate infected microbes before prosthesis implantation $[4,5]$. In addition, spacers maintain length of involved limbs and prevent muscle and soft tissue contracture via simple bone cement blocks inserting into the joint space [6-8]. Two types of antibiotic bone cement spacer are available, including articulating spacers and statics spacers. The arstructure of the normal knee joint, and thus has a good match with the residual bone surface. Meanwhile, it can 
maintain joint space and joint activity, reduce soft tissue adhesion, atrophy and scar formation, and reduce the recurrence rate of infection [6,9-11]. The static spacers can not only effectively deliver high concentration of antibiotic to control infection, but also maintain the joint space and limb length. However, the flexion and extension of the knee joint can result in soft tissue contracture around the joint and difficulty with reimplantation $[1,12]$. The use of articular bone cement spacer is becoming increasingly widespread. However, some researchers reported higher risks of complications and the infection rate for the articular bone cement spacers compared to static spacers [13, 14]. Currently, there exists controversy regarding which antibiotic spacers are superior in the treatment of infection following total knee arthroplasty. The aim of the present meta-analysis was to compare the clinical outcomes of static spacers with mobile spacers for the treatment of infection following TKA. This paper was conducted in strict accordance with the PICOS principle of formulating the inclusion criteria, and the related literatures were collected and retrieved at home and abroad.

\section{Methods}

\section{Search strategy}

We searched the ("Total knee arthroplasty" OR "TKA" OR "joint replacement") AND ("periprosthetic joint infection" OR "infection") AND ("two-stage revision" OR "revision") AND ("antibiotic bone cement spacer" OR "Spacers" OR "articulating Spacer" OR "static Spacer") in PubMed, EMBASE and the Cochrane Library during January 1960 and October 2016. No regional and ethnic restriction was employed. All the subjects were humans. The detailed search process is shown in Fig. 1.

\section{Inclusion and exclusion criteria}

Studies were considered to be eligible if they met the following criteria: (1) randomized controlled study, retrospective case-control study, or prospective cohort study of the two-stage revision of the first complete knee arthroplasty (which may include a small number of patients after knee revision surgery); (2) the study contains articulating group and static group; (3) the studies contains at least one of the following measured indicators: number of infection eradication, soft tissue contracture after the two-stage of surgery, recurrence of infection during the period of postoperative follow-up, range of motion after operation, postoperative follow-up joint function scores, and the complications (bone loss, mechanical complications, etc.).

Studies were excluded if they met the following criteria: (1) the total number of samples less than 20 cases of the study; (2) review literature, no control group literature, medical records reported literature; (3) the mean follow-up time less than 12 months; (4) studies

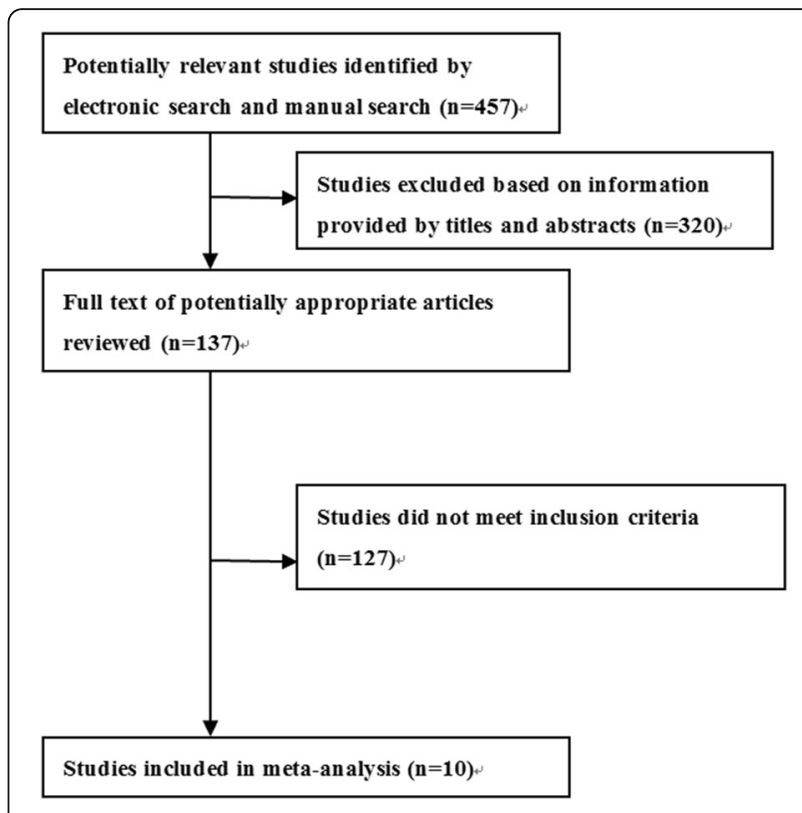

Fig. 1 Flowchart of literature search

from the same authors or repetitive reports; (5) poor quality observational studies; (6) non-English literature.

\section{Data extraction}

Literature data were extracted by Professor Ding Hai independently, and another two assistants validated these literatures. Any disagreement between reviewers was resolved by Professor Ding Hai. The data extracted included the first author, publication time, the type of study, the sample size, the patient's age, the average follow-up time, the type of antibiotic, the type of arthroplasty, the degree of preoperative joint activity, the degree of joint activity after revision at the final followup, number of recurrent infection at the final follow-up, knee score at the final follow-up, number of soft tissue angioplasty in the two stages of surgery, and postoperative complications (e.g., loss of bone loss and mechanical complications) at the final follow-up.

\section{Quality evaluation}

Among the ten included studies, nine were retrospective case-control and one was a prospective cohort study. Newcastle-Ottawa Scale (NOS) scale was used to evaluate the literature quality [15]. NOS adopt the semiquantitative principle of the star system. Nine stars represented the highest quality followed by high quality ( 5 to 9 stars), and low quality between zero and four stars.

\section{Statistical analysis}

Review Manager 5.3 software was used for data analysis. The count data was expressed as the rates or the composition ratio. The odds ratio (OR) and 95\% confidence 
interval (CI) were used to calculate the effect size. The measurement data were recorded by the mean and standard deviation (SD). The difference of the postoperative curative effect was based on the mean difference (MD) and the 95\% CI. Then, we drew the forest map. $P<0.05$ was considered to be statistically significant. Heterogeneity was assessed with the chi-square test value and $I^{2}$ value. Chi-square value of less than 0.1 and $I^{2}>50 \%$ denoted a large heterogeneity among the included literatures, and the random effects model (RE) can be used to calculate the effect indicators. Conversely, the fixed effect model (FE) will apply. It should be noted that the heterogeneity of the source should be assessed if there is significant heterogeneity among the subjects.

\section{Results}

\section{Study selection}

Four hundred fifty-seven potentially eligible literatures were identified based on electronic databases search. After reviewing the titles and abstracts, 320 literatures did not meet the inclusion criteria. Subsequently, the full texts of the remaining 137 literatures were examined carefully. After excluding literatures with incomplete data, non-controls and those which are duplicated, a total of ten studies were finally included in this study $[6-8,16-22]$. All the included literatures were deemed suitable for our inclusion criteria in this meta-analysis. The search process is shown in Fig. 1.

\section{Literature characteristics}

The characteristics of the included studies were summarized in Table 1. There were 236 spacers in the articulating group and 256 in the static group. The number of samples ranged from 29 to 115 , the mean postoperative follow-up period was more than 12 months. The antibiotic type of bone cement is mainly vancomycin or tobramycin, and then gentamicin or erythromycin. Articulating spacers can be divided into three types according to the production process: bone cement-bone cement type, metal-polyethylene type, and original pseudo-body type. Among the ten literatures, there was cement-bone cement type in six literatures, metalpolyethylene type in one literature, original pseudo-type in two literatures, and three coexisting type 1 literature. The NOS scores for these documents showed greater than 5 points, belonging to higher quality literature. The baseline information of the specific documents is shown in Table 1.

Table 1 Study characteristics

\begin{tabular}{|c|c|c|c|c|c|c|c|c|c|}
\hline \multirow[b]{2}{*}{ Study } & \multirow[b]{2}{*}{$\begin{array}{l}\text { Type of } \\
\text { study }\end{array}$} & \multicolumn{2}{|l|}{ Number of knees } & \multirow[b]{2}{*}{$\begin{array}{l}\text { Age } \\
\text { (A/S years) }\end{array}$} & \multirow[b]{2}{*}{$M / F$} & \multirow[b]{2}{*}{$\begin{array}{l}\text { Follow-up } \\
\text { (months) }\end{array}$} & \multirow[b]{2}{*}{ Type of antibiotic } & \multirow[b]{2}{*}{$\begin{array}{l}\text { Type of } \\
\text { articulating } \\
\text { positioner }\end{array}$} & \multirow[b]{2}{*}{$\begin{array}{l}\text { Literature } \\
\text { quality (NOS) }\end{array}$} \\
\hline & & $\begin{array}{l}\text { Articulating } \\
\text { spacer group }(A)\end{array}$ & $\begin{array}{l}\text { Static spacer } \\
\text { group(S) }\end{array}$ & & & & & & \\
\hline $\begin{array}{l}\text { Brunnekreef } \\
\text { J } 2013\end{array}$ & Retrospective & 26 & 9 & $61 / 58$ & $\begin{array}{l}15 / \\
20\end{array}$ & 12 & $\begin{array}{l}\text { Gentamycin/ } \\
\text { erythromycin }\end{array}$ & $\begin{array}{l}\text { Metal } \\
\text {-polyethylene }\end{array}$ & 8 \\
\hline $\begin{array}{l}\text { Johnson AJ } \\
2012\end{array}$ & Retrospective & 34 & 81 & $62 / 61$ & NA & $27 / 66$ & $\begin{array}{l}\text { Vancomycin/ } \\
\text { tobramycin }\end{array}$ & $\begin{array}{l}\text { Three different } \\
\text { types }\end{array}$ & 7 \\
\hline $\begin{array}{l}\text { Choi HR } \\
2012\end{array}$ & Retrospective & $14(10)$ & $33(31)$ & 64 & $\begin{array}{l}23 / \\
24\end{array}$ & 58 & $\begin{array}{l}\text { Vancomycin/ } \\
\text { tobramycin }\end{array}$ & $\begin{array}{l}\text { Original implant- } \\
\text { bone cement }\end{array}$ & 7 \\
\hline $\begin{array}{l}\text { Chiang ER } \\
2011\end{array}$ & Prospective & $23(22)$ & $22(21)$ & $71 / 72$ & $\begin{array}{l}22 / \\
23\end{array}$ & $41 / 40$ & Vancomycin & $\begin{array}{l}\text { Bone cement- } \\
\text { bone cement }\end{array}$ & 7 \\
\hline $\begin{array}{l}\text { Park SJ } \\
2010\end{array}$ & Retrospective & 16 & 20 & $66.5 / 60.2$ & $4 / 32$ & $36 / 29$ & $\begin{array}{l}\text { Vancomycin/ } \\
\text { erythromycin }\end{array}$ & $\begin{array}{l}\text { Bone cement- } \\
\text { bone cement }\end{array}$ & 8 \\
\hline $\begin{array}{l}\text { Freeman } \\
\text { MG } 2007\end{array}$ & Retrospective & 48 & 28 & $64.9 / 71.2$ & NA & $\begin{array}{l}\text { Total } 71.2 \\
62.2 / 86.6\end{array}$ & $\begin{array}{l}\text { Vancomycin/ } \\
\text { tobramycin }\end{array}$ & $\begin{array}{l}\text { Bone cement- } \\
\text { bone cement }\end{array}$ & 6 \\
\hline $\begin{array}{l}\text { Hsu YC } \\
2007\end{array}$ & Retrospective & 21 & 7 & - & NA & $58 / 101$ & $\begin{array}{l}\text { Vancomycin/ } \\
\text { tobramycin or } \\
\text { gentamicin }\end{array}$ & $\begin{array}{l}\text { Bone cement- } \\
\text { bone cement }\end{array}$ & 8 \\
\hline $\begin{array}{l}\text { Jämsen E } \\
2006\end{array}$ & Retrospective & $24(22)$ & $10(8)$ & $68 / 70$ & $\begin{array}{l}11 / \\
23\end{array}$ & 32 & NA & $\begin{array}{l}\text { Original implant- } \\
\text { bone cement }\end{array}$ & 8 \\
\hline $\begin{array}{l}\text { Emerson RH } \\
2002\end{array}$ & Retrospective & 22 & 26 & $65.1 / 65.7$ & $\begin{array}{l}17 / \\
31\end{array}$ & $45.6 / 90$ & $\begin{array}{l}\text { Vancomycin/ } \\
\text { tobramycin }\end{array}$ & $\begin{array}{l}\text { Bone cement- } \\
\text { bone cement }\end{array}$ & 8 \\
\hline $\begin{array}{l}\text { Fehring TK } \\
2000\end{array}$ & Retrospective & $30(15)^{a}$ & 25 & NA & NA & $27 / 36$ & Tobramycin & $\begin{array}{l}\text { Bone cement- } \\
\text { bone cement }\end{array}$ & 7 \\
\hline
\end{tabular}

Note: (1) The number in brackets in the sample size is the actual number of patients who completed the second revision and implantation of the new prosthesis (excluding the last document); (2) "NA" indicates that no information is available in the literature

${ }^{a}$ Fifteen is the number of patients who have actually completed follow-up 


\section{Clinical outcomes}

\section{Infection eradication}

Among ten articles were evaluated by the infection eradication [6-8, 16-22]. There was no significant heterogeneity among these included subjects $\left(\chi^{2}=3.68\right.$, $\left.i^{2}=0, P=0.88\right)$. The fixed effect model was used for data analysis, and the results showed that there was no significant difference regarding the eradication rate between the articulating and statics spacers in the twostage revision surgery of postoperative infection after TKA $(\mathrm{OR}=1.18,95 \% \mathrm{CI}: 0.66 \sim 2.11, P=0.59)$ Fig. 2$)$.

\section{The release rate of soft tissue in two-stage revision (lengthening of the femoral quadriceps)}

Among five literatures [7, 8, 18, 19, 21] were reported the release rate of soft tissue in two-stage revision (lengthening of the femoral quadriceps). There was moderate heterogeneity among the objects of study $\left(\chi^{2}=7.95, I^{2}=50 \%, P=0.09\right)$ and using a random effects model. The results showed no significant difference regarding the release rate of soft tissue between articulating and static spacers in the two-stage revision of infection after TKA $(\mathrm{OR}=0.65,95 \% \mathrm{CI}: 0.19 \sim 2.29$, $P=0.50$ ) (Fig. 3).

\section{The release rate of soft tissue in two-stage revision (tibial} tubercle osteotomy)

Among three literatures were evaluated the release rate of soft tissue (tibial tubercle osteotomy) in two-stage revision of infection after TKA $[8,16,18]$. There was a big heterogeneity between the object of these studies $\left(\chi^{2}=6.44, I^{2}=69 \%, P=0.04\right)$. Random effects model was used for analysis. The results showed no significant difference between articulating and static spacers in the two-stage revision of infection after TKA regarding soft tissue release rate (tibial tubercle osteotomy) $(\mathrm{OR}=0.55$, 95\% CI 0.10 to $3.13, P=0.50$ ) (Fig. 4 ).

\section{Range of motion}

Eight studies [6-8, 16-18, 21, 22] assessed the range of motion in this meta-analysis. There was a moderate heterogeneity among the subject in these studies $\left(\chi^{2}=16.73\right.$, $\left.I^{2}=52 \%, P=0.03\right)$. Random effects model was used for analysis. The articulating group had greater postoperative ROM than the static group $\left(\mathrm{MD}=12.19^{\circ}, 95 \% \mathrm{CI}\right.$ 6.80 17.58, $P<0.00001$ ) (Fig. 5).

\section{KSS (function) score}

Four studies assessed KSS (function) score [8, 20-22]. There was no significant heterogeneity between the object of these studies $\left(\chi^{2}=3.61, I^{2}=17 \%, P=0.31\right)$. The fixed effect model was used for data analysis. There was a statistically significant difference between the articulating and static groups regarding KSS (function) score, and the articulating group had higher postoperative KSS (function) score than the static group (MD $=9.17,95 \%$ CI 2.29 16.04, $P=0.009$ ) (Fig. 6).

\section{KSS (pain) score}

Only three studies reported KSS (pain) score [8, 20, 22]. There was no significant heterogeneity between the object of these studies $\left(\chi^{2}=1.51, I^{2}=0 \%, P=0.47\right)$. The fixed effect model was used for data analysis. There was no statistically significant difference between the articulating and static groups regarding KSS (pain) score $(\mathrm{MD}=2.90,95 \% \mathrm{CI}:-6.48 \sim 0.67, P=0.11)$ (Fig. 7 ).

\section{Hospital for Special Surgery (HSS) score}

Three studies assessed HHS score [7, 8, 19] in the twostage revision of infection after TKA. There was no significant heterogeneity between the object of these studies $\left(\chi^{2}=1.84, I^{2}=0 \%, P=0.40\right)$. The fixed effect model was used for data analysis. There was a statistically significant difference between the articulating and static groups regarding HSS score, and the articulating group

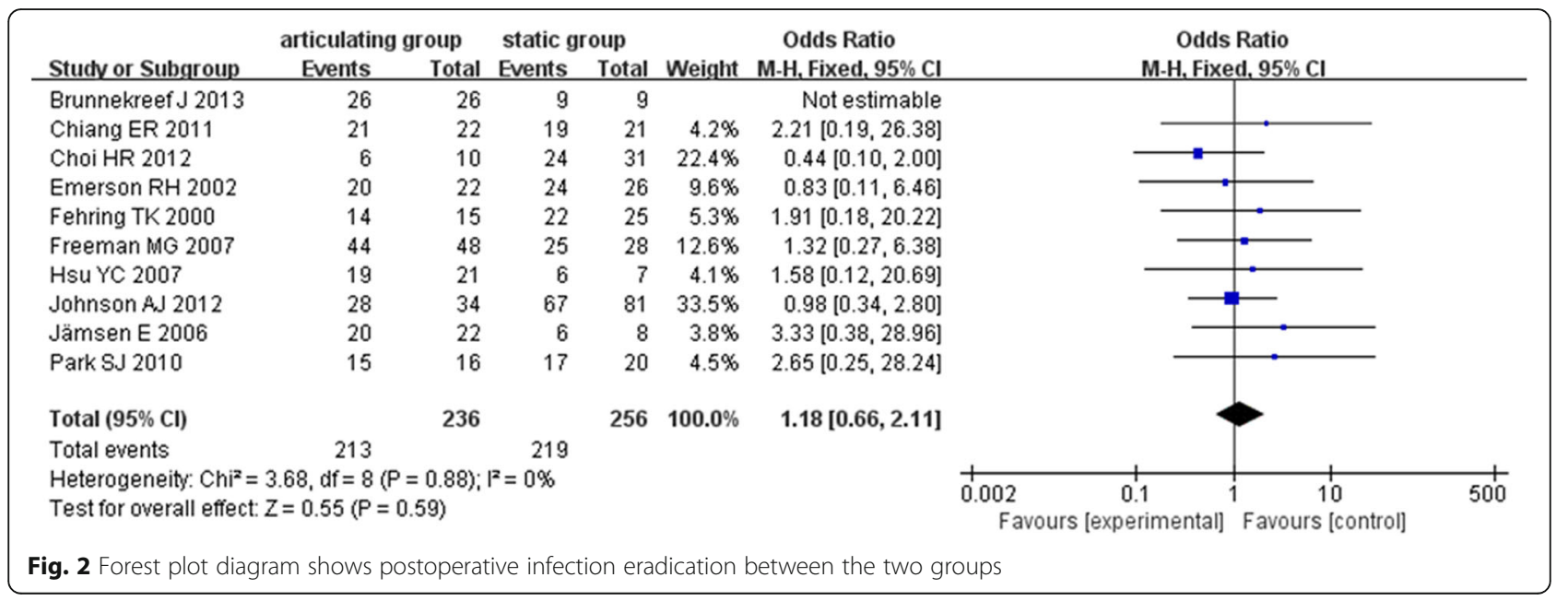




\begin{tabular}{|c|c|c|c|c|c|c|c|c|c|}
\hline \multirow[b]{2}{*}{ Studv or Subgroup } & \multicolumn{2}{|c|}{ articulating group } & \multicolumn{2}{|c|}{ static group } & \multirow{2}{*}{ Weight } & \multirow{2}{*}{$\begin{array}{c}\text { Odds Ratio } \\
\text { M-H, Random, } 95 \% \mathrm{Cl}\end{array}$} & \multirow{2}{*}{\multicolumn{3}{|c|}{$\begin{array}{c}\text { Odds Ratio } \\
\text { M-H, Random, } 95 \% \mathrm{Cl}\end{array}$}} \\
\hline & Events & Total & Events & Total & & & & & \\
\hline Chiang ER 2011 & 0 & 22 & 7 & 21 & $12.7 \%$ & $0.04[0.00,0.81]$ & & & \\
\hline Choi HR 2012 & 3 & 10 & 6 & 31 & $24.7 \%$ & $1.79[0.35,9.02]$ & & & \\
\hline Fehring TK 2000 & 2 & 15 & 2 & 25 & $19.6 \%$ & $1.77[0.22,14.09]$ & & & \\
\hline Hsu YC $200 ?$ & 1 & 21 & 2 & 7 & $15.0 \%$ & $0.13[0.01,1.67]$ & & & \\
\hline Park SJ 2010 & 6 & 16 & 7 & 20 & $28.0 \%$ & $1.11[0.28,4.37]$ & & & \\
\hline Total (95\% Cl) & & 84 & & 104 & $100.0 \%$ & $0.65[0.19,2.29]$ & & & \\
\hline Total events & 12 & & 24 & & & & & & \\
\hline $\begin{array}{l}\text { Heterogeneity: Tau } \\
\text { Test for overall effec }\end{array}$ & $\begin{array}{l}0.98 ; \mathrm{Chi}^{2}= \\
\mathrm{Z}=0.67(\mathrm{P}\end{array}$ & $\begin{array}{l}5, d f= \\
50)\end{array}$ & $4(P=0.0$ & $9 ; 1^{2}=5$ & $50 \%$ & & $\begin{array}{ccc}0.001 & 0.1 & 1 \\
\text { Favours [experimental] }\end{array}$ & $\begin{array}{l}10 \\
\text { Favours [control] }\end{array}$ & 1000 \\
\hline
\end{tabular}

had higher postoperative HSS score than the static group $(\mathrm{MD}=7.00,95 \% \mathrm{CI}: 3.91 \sim 10.10, P<0.00001)$ (Fig. 8).

\section{Bone loss}

There was less bone loss in the articulating group than in the static group [7, 8, 17, 21]. Fehring and Park reported that there was no bone loss in the articulating group [7, 8]. And Johnson and his colleague [17] demonstrated that more patients had severe bone loss in the static group (80\%) than in the articulating group (53\%). Femoral and tibial bone loss was $100 \%$ of the knees in the static group, while in the articulating group, only $28.6 \%$ of the knees with femoral bone loss, $47.6 \%$ of the knees with tibial bone loss [21].

\section{Publication bias}

The graphical funnel plot may of included studies for outcome measurements appeared to be symmetrical (Fig. 9). The spots are evenly distributed on both sides of the inverted funnel, suggesting that there was no significant publication bias in the retrieved documents.

\section{Discussion}

TKA has been regarded as an effective way to treat knee joint osteoarthritis, rheumatoid arthritis, and other advanced knee disorders since 1968. With the continuous improvement of surgical techniques and prosthetic design, TKA has become one of the most successful techniques in orthopedics. With the aging of the population, the demand for total knee replacement is still increasing. The increase in the amount of surgery is associated with increasing postoperative complications, of which PJI is one of the greatest complications. The current "gold standard" for the treatment of periprosthetic infection is still the two-stage revision surgery, which can fundamentally eliminate the infection and create healthy and vigorous tissue for the preparation of new prosthesis implantation [23]. During the two-stage revision, the doctor's main goal is to prevent soft tissue contracture around the joint, which may lead to second operation exposure and refurbished prosthetic implant difficulties, and thus increased the surgical difficulties [24]. Therefore, it is crucial to maintain the stability of the knee joint and the balance of the soft tissue around the joint during the exclusion period of antibiotic bone cement. Moreover, there was a certain concentration of antibiotics in the knee joint to eradicate the infection $[25,26]$. Currently, the antibiotic bone cement spacer can be divided into two categories, articulating type (hinge type) and static type (fixed type), and there was a significant controversy about whether articulating or static spacers can provide better outcomes. In this metaanalysis, we analyzed the difference of the two spacers regarding postoperative effects, including the infection eradication rate, the soft tissue release rate during the two-stage revision surgery, the ROM after the revision surgery, and function scores.

There was no significant difference between the two spacers regarding eradicate rate of infection in this

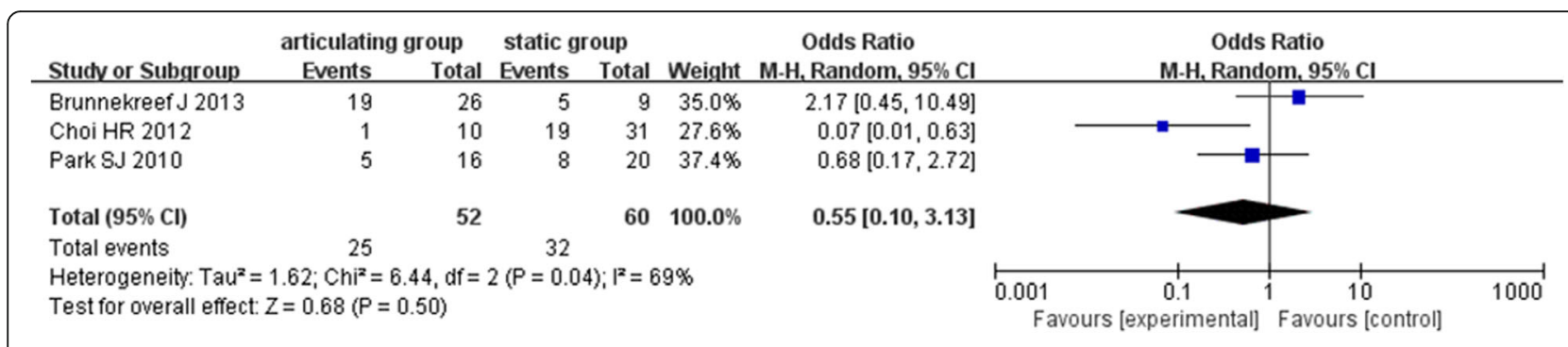

Fig. 4 Forest plot diagram shows the tibial tubercle osteotomy between the two groups 


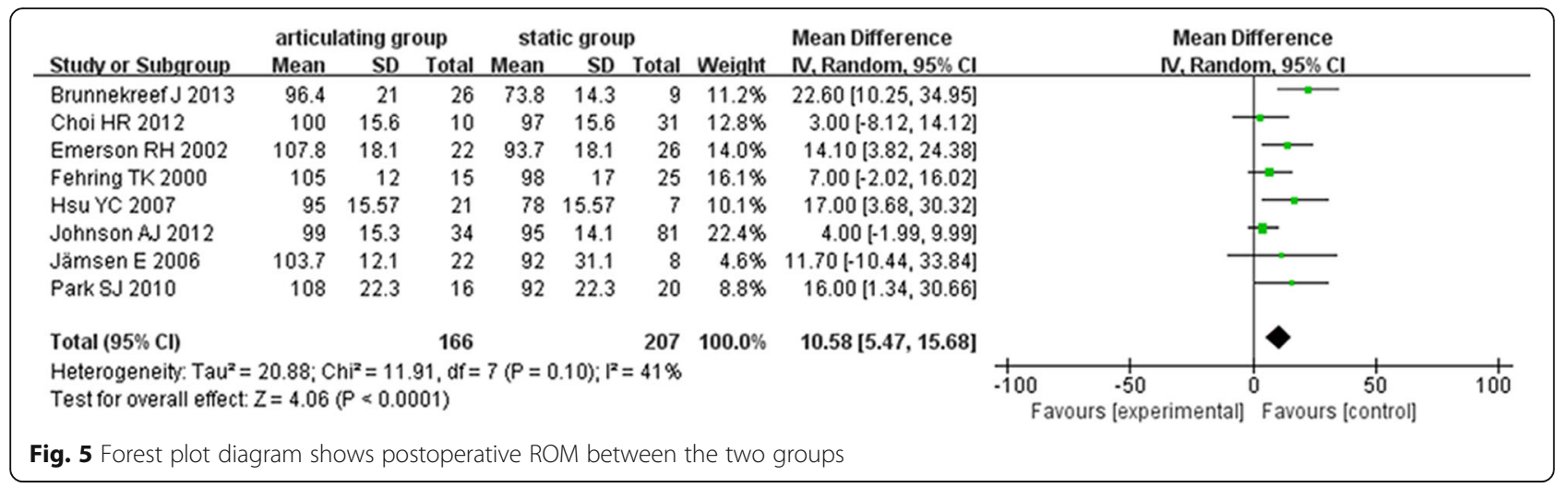

study. The majority of the included articles reported the similar antibiotic use time, antibiotics for at least 6 weeks in vivo during the period of spacers $[6-8,16-18,20-$ 22]. There is no consistent standard for the best mix of methods for preparing high-dose antibiotic bone cement spacers. Most of the antibiotics associated with spacers mainly vancomycin (1 4 g of added $40 \mathrm{~g}$ bone cement) or gentamicin, tobramycin (2.4 4.8 g of added $40 \mathrm{~g}$ bone cement) [25]. Bone cement spacers should have a sufficiently high level of antibiotic to provide a relatively high concentration of local tissue release levels, while the dose of antibiotics should be low enough to prevent the mechanical properties of bone cement spacers weakened [27]. John F. Nettrour et al. [28] reported that there was no dose-dependent of antibiotic bone cement. Voleti et al. [29] compared the clinical effects between the articulating and static groups, 1526 patients were included in their systematic review (872 cases of articulating spacers and 654 cases of statics spacers). Their findings indicated no statistical significance difference regarding the infection eradication. The results of Voleti et al. study are consistent with Piver et al. [30] study. In contrast, Romano et al. [31] showed that the articulating spacers can achieve higher infection eradication than the static spacers (91.2 versus $87 \%$ ). However, some authors suggested that the static spacer can provide greater release and space for the soft tissue around the joint infection or blood transfusion and can better eliminate the infection [32].
ROM and functional recovery are indicators of postoperative efficacy. In this meta-analysis, the results of ROM and KSS (function) score in articulating group significance were higher than in the static group. However, there was no significant difference regarding HSS and KSS (pain) score between the two groups. Dr. Javad Parvizi and Thorsten Gehrke concluded that there was an encouraging postoperative function in patients which were treated with articulating spacers in the two-stage revision of the knee surgery. In contrast, the increasing trend of ROM in statics spacers was higher than those patients with articulating spacers after follow-up for 2 years. Their results were consistent with some larger scale systematical reviews [29, 30,33].

In this study, the soft tissue release rate during the two-stage revision surgery was used to assess whether there were differences regarding soft tissue contracture between the two different spacers. The results showed that there was no significant difference between either quadriceps or tibial tubercle osteotomy in two different spacers. However, Guild et al. [33] found that the patients with articulating spacers were less associated with the assistive technology than those with static spacers. The reason may be that knee activities during the exclusion period helps to maintain the length and flexibility of the extensor device and prevent the formation of scar tissue around the knee, quadriceps shortening, and joint capsule thickening and contracture [34]. The results of our study suggest no significant difference regarding the

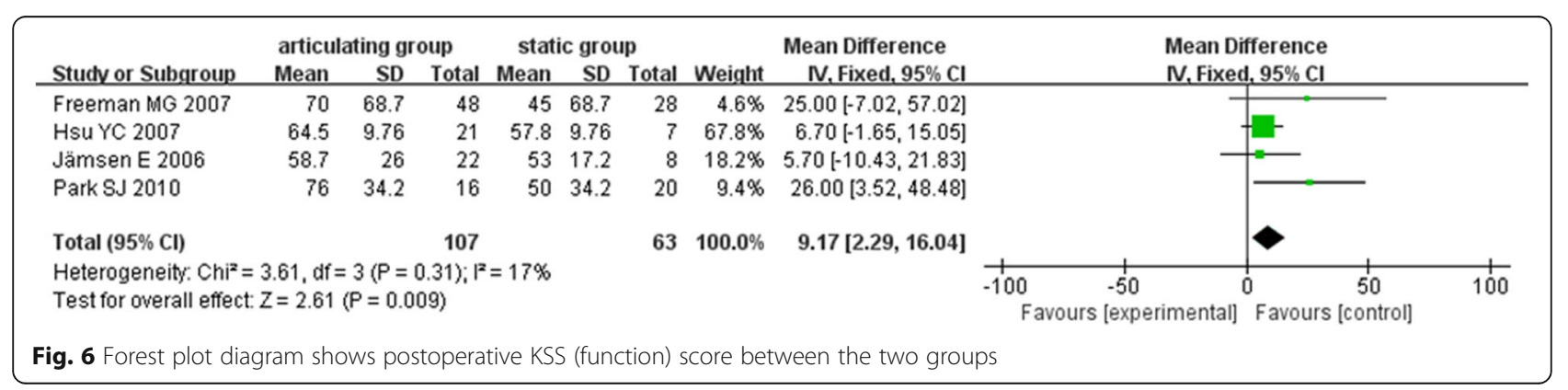




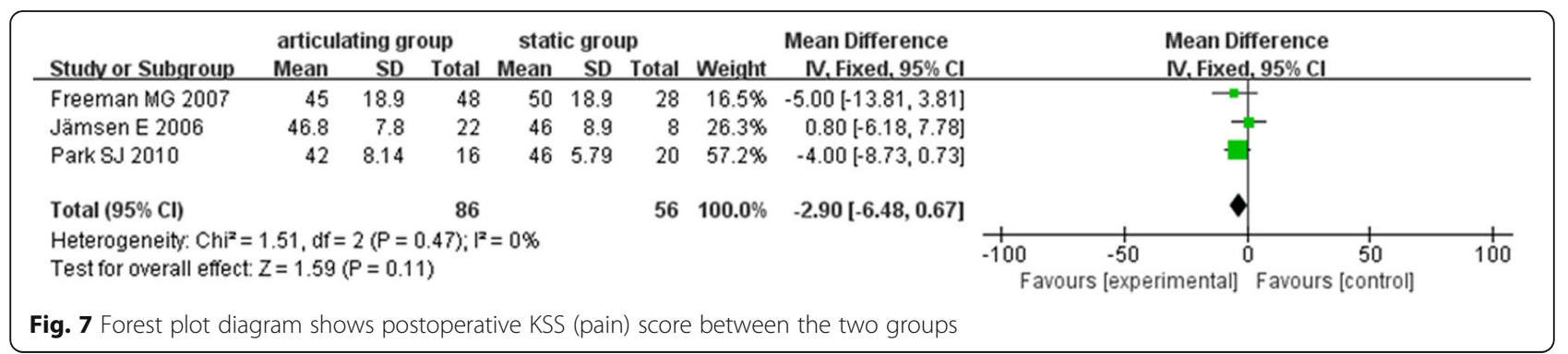

soft tissue release rate, which may be due to the relatively small number of participants and sample size. Randomized controlled studies with larger number of samples are still required.

Bone loss is also a common complication during the exclusion period. Guild et al. [33] reported that there was less bone loss in articulating group than the static group. A retrospective case-control study [8] reported that $15(75 \%)$ patients had pre-existing tibial or femoral bone loss in the static group, 10 cases (65\%) had preexisting tibial bone loss, 13 (65\%) patients had femoral bone loss, and 8 patients had tibial bone loss. However, there was no bone loss in the articulating group. Some researchers demonstrated that the static spacers did not restore the normal knee anatomical profile [35]. In the traditional "block" static spacers, the bone cement surface and the bone surface are in point-like contact; the uneven pressure distribution and the local high point pressure lead to a large amount of bone loss during the exclusion period. However, with the continuous updating of the static type of the design of the spacers, there has been "internal skeleton" type static spacer, and the stability of the knee joint will be further strengthened. Yoo et al. [36] reported that the four patients using an internal skeleton-type static spacer showed excellent clinical outcomes and no bone loss, and noted that this technique may be more suitable for patients with suspected bone loss after removal of the prosthesis. For these patients, the articulating spacers cannot provide sufficient stability. Most of the included literatures did not provide sufficient data for the bone loss in our research.
There are several limitations in this meta-analysis. (1) There were no RCTs in this article, and retrospective case-control studies inevitably lead to the recall bias and the confounding bias between subjects and will lead to objectivity influences. (2) The length of follow-up period in patients with static and articulating groups was different in some literatures. Each article had different followup time. Although the duration of follow-up was greater than 12 months, the deviation caused by different follow-up time may also affect the objectivity of the results. (3) All included studies did not specify any inclusion or exclusion criteria to determine which patients would receive the articulating spacers or the static spacers, resulting in considerable selection bias. (4) All the included patients in this study had larger age span. The differences in medical and health levels will lead to greater differences in postoperative efficacy. (5) During the data extraction of some continuous variable data, only the mean values were available in the literature; therefore, the standard deviation was obtained by averaging and the $P$ value or $95 \%$ CI [37], which may lead to bias in the outcome and affect the objectivity. (6) Due to the limited number of literature, it was not possible to provide sufficient data for subgroup analysis, which may be one of the sources of heterogeneity.

\section{Conclusion}

In this meta-analysis, we found no significant difference between articulating and static spacers in terms of infection eradication, the soft tissue contracture, and the knee pain scores. The patients with articulating spacers were able to achieve better ROM and limb function, but there

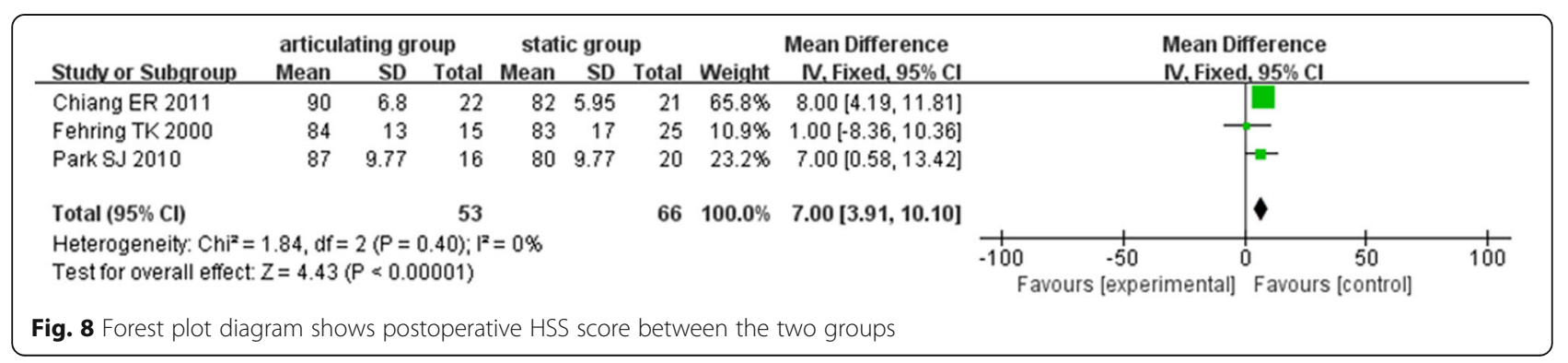




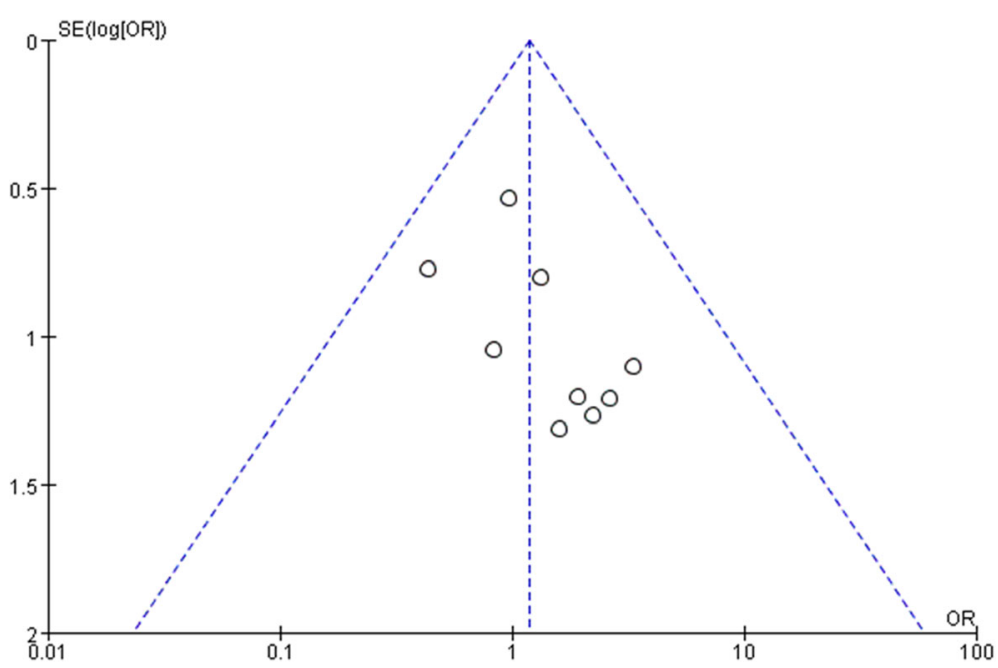

Fig. 9 The graphical funnel plot

was no significant difference in postoperative pain between the static and articulating spacers. Further randomized controlled studies on these two different spacers are still required to be carried out to provide more accurate and objective data for a comprehensive and accurate analysis.

\section{Abbreviations}

Cl: Confidence interval; FE: Fixed effect model; HSS: Hospital for special surgery knee score; KSS: American Knee Society knee score; MD: Mean difference; NOS: Newcastle-Ottawa Scale; OR: Odds ratio; PJI: Prosthetic joint infection; RE: Random effects; SD: Standard deviation; TKA: Total knee arthroplasty

\section{Acknowledgements}

None

\section{Funding}

None.

\section{Availability of data and materials}

Please contact the author for data requests.

\section{Authors' contributions}

HD conceived the manuscript and wrote the manuscript. JY interpreted the patient data. WC collected and analyzed the patient data. FL searched literatures. All authors read and approved the final manuscript.

\section{Ethics approval and consent to participate}

Not applicable.

\section{Consent for publication}

Not applicable.

\section{Competing interests}

The authors declare that they have no competing interests.

\section{Publisher's Note}

Springer Nature remains neutral with regard to jurisdictional claims in published maps and institutional affiliations.
Received: 28 June 2017 Accepted: 26 September 2017

Published online: 17 October 2017

\section{References}

1. Kurtz SM, Lau E, Schmier J, Ong KL, Zhao K, Parvizi J. Infection burden for hip and knee arthroplasty in the United States. J Arthroplast. 2008;23(7):98491. https://doi.org/10.1016/j.arth.2007.10.017.

2. Kurtz SM, Ong KL, Lau E, Bozic KJ, Berry D, Parvizi J. Prosthetic joint infection risk after TKA in the Medicare population. Clin Orthop Relat Res. 2010:468(1): 52-6. https://doi.org/10.1007/s11999-009-1013-5.

3. Sherrell JC, Fehring TK, Odum S, Hansen E, Zmistowski B, Dennos A, et al. The Chitranjan Ranawat Award: fate of two-stage reimplantation after failed irrigation and debridement for periprosthetic knee infection. Clin Orthop Relat Res. 2011:469(1):18-25. https://doi.org/10.1007/s11999-010-1434-1.

4. Parvizi J, Della Valle CJ. AAOS Clinical Practice Guideline: diagnosis and treatment of periprosthetic joint infections of the hip and knee. J Am Acad Orthop Surg. 2010;18(12):771-2.

5. Lonner JH, Barrack R, Fitzgerald RH Jr, Hanssen AD, Windsor ER. Infection in total knee arthroplasty: part I. Classification, prophylaxis, and diagnosis. American journal of orthopedics (Belle Mead, NJ) 1999;28(9):530-535.

6. Jr ER, Muncie M, Tarbox TR, Higgins LL. Comparison of a static with a mobile spacer in total knee infection. Clin Orthop Relat Res. 2002;404(404): 132.

7. Fehring TK, Odum S, Calton TF, Mason JB. Articulating versus static spacers in revision total knee arthroplasty for sepsis. The Ranawat Award. Clin Orthop Relat Res. 2000;380(380):9-16.

8. Park SJ, Song EK, Seon JK, Yoon TR, Park GH. Comparison of static and mobile antibiotic-impregnated cement spacers for the treatment of infected total knee arthroplasty. Int Orthop. 2010;34(8):1181-6.

9. Toms AD, Davidson D, Masri BA, Duncan CP. The management of periprosthetic infection in total joint arthroplasty. J Bone Joint Surg. 2006;88(88): $149-55$

10. Pitto RP, Castelli CC, Ferrari R, Munro J. Pre-formed articulating knee spacer in two-stage revision for the infected total knee arthroplasty. Int Orthop. 2005:29(5):305-8.

11. Kraay MJ, Goldberg VM, Fitzgerald SJ, Salata MJ. Cementless two-staged total hip arthroplasty for deep periprosthetic infection. Clin Orthop Relat Res. 2006:441(441):243-9.

12. Calton TF, Fehring TK, Griffin WL. Bone loss associated with the use of spacer blocks in infected total knee arthroplasty. Clin Orthop Relat Res. 1997;345(345):148-54.

13. Klekamp J, Dawson JM, Haas DW, Deboer D, Christie M. The use of vancomycin and tobramycin in acrylic bone cement: biomechanical effects and elution kinetics for use in joint arthroplasty. J Arthroplast. 1999:14(3): $339-46$. 
14. Pietsch M, Hofmann S, Wenisch C. Zweizeitiger Prothesenwechsel bei infizierter Knieendoprothese. Oper Orthop Traumatol. 2006;18(1):66-87.

15. Asadollahi S, Sorial R, Coffey S, Gupta M, Eslick GD. Total knee arthroplasty after patellectomy: a meta-analysis of case-control studies. Knee. 2017;24(2): 191-6. https://doi.org/10.1016/j.knee.2017.01.004.

16. Brunnekreef J, Hannink G, Malefijt MW. Recovery of knee mobility after a static or mobile spacer in total knee infection. Acta Orthop Belg. 2013;79(1):83-9.

17. Johnson AJ, Sayeed SA, Naziri Q, Khanuja HS, Mont MA. Minimizing dynamic knee spacer complications in infected revision arthroplasty. Clin Orthop Relat Res. 2012;470(1):220-7.

18. Choi HR, Malchau H, Bedair H. Are prosthetic spacers safe to use in 2-stage treatment for infected total knee arthroplasty? J Arthroplast. 2012;27(8):1474-9.e1.

19. Chiang ER, Su YP, Chen TH, Chiu FY, Chen WM. Comparison of articulating and static spacers regarding infection with resistant organisms in total knee arthroplasty. Acta Orthop. 2011;82(4):460.

20. Freeman MG, Fehring TK, Odum SM, Fehring K, Griffin WL, Mason JB. Functional advantage of articulating versus static spacers in 2-stage revision for total knee arthroplasty infection. J Arthroplast. 2007;22(8):1116.

21. Hsu YC, Cheng HC, Ng TP, Chiu KY. Antibiotic-loaded cement articulating spacer for 2-stage reimplantation in infected total knee arthroplasty : a simple and economic method. J Arthroplast. 2007;22(7):1060-6.

22. Jämsen PS E, Halonen P, Lehto MUK, Moilanen T, Pajamäki J, Puolakka T, Konttinen YT. Spacer prostheses in two-stage revision of infected knee arthroplasty. Int Orthop. 2006;30(4):257-61.

23. larikov D, Demian H, Rubin D, Alexander J, Nambiar S. Choice and doses of antibacterial agents for cement spacers in treatment of prosthetic joint infections: review of published studies. Clin Infect Dis. 2012;55(11):1474.

24. Antoci V, Phillips MJ, Krackow KA. The treatment of recurrent chronic infected knee arthroplasty with a 2-stage procedure. J Arthroplast. 2009; 24(1):13-7.

25. Jacobs $C$, Christensen CP, Berend ME. Static and mobile antibiotic-impregnated cement spacers for the management of prosthetic joint infection. J Am Acad Orthop Surg. 2009;17(6):356-68.

26. Incavo SJ, Russell RD, Mathis KB, Adams $\mathrm{H}$. Initial results of managing severe bone loss in infected total joint arthroplasty using customized articulating spacers. J Arthroplast. 2009;24(4):607-13.

27. Paz E, Sanzruiz P, Abenojar J, Vaqueromartín J, Forriol F, Del Real JC. Evaluation of elution and mechanical properties of high-dose antibiotic-loaded bone cement: comparative "in vitro" study of the influence of vancomycin and cefazolin. J Arthroplast. 2015;30(8):1423-9.

28. Nettrour JF, Polikandriotis JA, Bernasek TL, Gustke KA, Lyons ST. Articulating spacers for the treatment of infected total knee arthroplasty: effect of antibiotic combinations and concentrations. Orthopedics. 2013;36(1):19-24

29. Voleti PB, Baldwin KD, Lee GC. Use of static or articulating spacers for infection following total knee arthroplasty: a systematic literature review. J Bone Joint Surg (Am Vol). 2013;95(17):1594-9.

30. Pivec R, Naziri Q, Issa K, Banerjee S, Mont MA. Systematic review comparing static and articulating spacers used for revision of infected total knee arthroplasty. J Arthroplast. 2014;29(3):553-7.

31. Romanò CL, Gala L, Logoluso N, Romanò D, Drago L. Two-stage revision of septic knee prosthesis with articulating knee spacers yields better infection eradication rate than one-stage or two-stage revision with static spacers Knee Surgery Sports Traumatology Arthroscopy Official Journal of the Esska. 2012;20(12):2445-53.

32. Faschingbauer M, Bieger R, Reichel H, Weiner C, Kappe T. Complications associated with 133 static, antibiotic-laden spacers after TKA. Knee Surg Sports Traumatol Arthrosc. 2015;24(10):1-4.

33. Rd GG, Wu B, Scuderi GR. Articulating vs. static antibiotic impregnated spacers in revision total knee arthroplasty for sepsis. A systematic review. J Arthroplast. 2014;29(3):558-63.

34. Thabe H, Schill S. Two-stage reimplantation with an application spacer and combined with delivery of antibiotics in the management of prosthetic joint infection. Oper Orthop Traumatol. 2007;19(1):78-100.

35. Shen $H$, Zhang $X$, Jiang $Y$, Wang $Q$, Chen $Y$, Wang $Q$ et al. Intraoperativelymade cement-on-cement antibiotic-loaded articulating spacer for infected total knee arthroplasty 2010;17(6):407-11.

36. Yoo J, Lee S, Han C, Chang J. The modified static spacers using antibioticimpregnated cement rod in two-stage revision for infected total knee arthroplasty. Clinics in Orthopedic Surgery. 2011;3(3):245-8.

37. Higgins JP, Green S. Cochrane handbook of systematic reviews of interventions. Wiley-Blackwell. 2008:5(14):102-8.

\section{Submit your next manuscript to BioMed Central and we will help you at every step:}

- We accept pre-submission inquiries

- Our selector tool helps you to find the most relevant journal

- We provide round the clock customer support

- Convenient online submission

- Thorough peer review

- Inclusion in PubMed and all major indexing services

- Maximum visibility for your research

Submit your manuscript at www.biomedcentral.com/submit
Biomed Central 